\title{
Chapter 11 and the Level Playing Field: Should Chapter 11 be Considered as a Subsidy?
}

Sebastian Bock ${ }^{\mathrm{a}}$, Peter Forsyth ${ }^{\mathrm{b}}$, Hans-Martin Niemeier ${ }^{\mathrm{c}}$, Benny Mantin ${ }^{\mathrm{d}}$

${ }^{a}$ University of Applied Sciences Bremen, Germany; SebastianBock@gmx.net

${ }^{b}$ Monash University and Southern Cross University, Australia; peter.forsyth@monash.edu

c University of Applied Sciences Bremen, Germany; Hans-Martin.Niemeier@hs-bremen.de

d Corresponding author, Director, Professor, Luxembourg Centre for Logistics and Supply Chain Management, University of Luxembourg, Faculty of Law, Economics and Finance (FDEF), 162A, Avenue de la Faïencerie, L-1511 Luxembourg, T +352 466644 5815;F +352 46664435815 benny.mantin@uni.lu

\begin{abstract}
This paper assesses whether Chapter 11 is a form of subsidy for US airlines. US airlines have used Chapter 11 many times to restructure their operations. This has been criticized as a subsidy by major non US airlines, airlines associations and governments for a long time. Recently, in the "level playing field" debate between the Gulf and US carriers, the former have claimed that Chapter 11 is a form of subsidy. Applying legal and economic perspectives of subsidy, we examine the different opportunities of Chapter 11 to reduce airlines' costs. It is argued that most of the forms available, such as the modification of collective bargaining or the renegotiation of debts, do not constitute a subsidy. Only the termination of pension plans might involve a subsidy, but only using a legal definition of doubtful relevance (involving the Pension Benefit Guaranty Corp, being a public body, but acting as an insurance agency funded by the participating firms), since there is normally no use of public funds.
\end{abstract}

Keywords: Level Playing Field, subsidies, bankruptcy protection, Chapter 11 
In the US, bankruptcy protection is regulated under Chapter 11 of the United States Bankruptcy Law. This mechanism, which allows firms to organize and restructure, has been employed by all major US network carriers in the past (as well as by thousands of other firms from every segment of the US economy). This process has been criticized as it allows potentially inefficient firms to reorganize (Hotchkiss, 1995), and that the outcome may be such that firms, or industries, will be left with chronic inefficiencies (Jensen, 1991). An example occurs with the US airline industry, which has experienced recurring filings for bankruptcy protection.

Major concerns have been expressed that Chapter 11 can be perceived as a form of a subsidy, which ultimately distorts the level playing field in domestic and especially international markets. In this paper, we concentrate on the latter. Existing studies (see overview by Tretheway and Andriulaitis, 2015) identify various factors that could tilt the level playing field in aviation. Subsidies play a major role in this regard, however bankruptcy protection laws, like Chapter 11, are not addressed.

In the discussion of aviation, it is often claimed that Chapter 11 involves a subsidy to US airlines. Chapter 11 has been characterised by IATA Vision 2050 (2010) as a market distorting subsidy and as an obstacle to raise the profitability to a normal level. The European and US delegations also disagreed on Chapter 11 in their negotiations for an Open Sky Area. However, the most recent, and most controversial, subsidy claim has been made by the Gulf airlines (Emirates, Etihad and Qatar Airways) in their response to the US airlines, which had argued that the Gulf countries subsidised their airlines, and thus there was not a "level playing field". The Gulf airlines responded by arguing that the US airlines were subsidised in several ways, including through Chapter 11.

This paper sheds light on the question as to whether Chapter 11 involves a subsidy or not from legal and economic points of view. In order to decide if Chapter 11 should be regarded as providing an avenue for subsidy, we analyse, firstly, the bankruptcy laws and regulations of the United States Code (U.S.C.) and identify the core opportunities which companies under Chapter 11 can use to avoid liquidation. Secondly, we define and compare the different legal and economic concepts of subsidies. Next, we consider the different ways in which Chapter 11 allows an airline to restructure its business and reduce its costs, and assess 
whether these involve subsidies. ${ }^{1}$ The analysis is then applied to two cases: the US-EU open skies area negotiations, as well as the ongoing "level playing field" dispute between the US and the Gulf airlines. In summary, we argue that there is no clearly relevant legal definition under which Chapter 11 involves a subsidy, and that Chapter 11 does not involve a subsidy under normal economic definitions of the term. ${ }^{2}$

\section{$2 \quad$ What is Chapter 11?}

Title 11 of the U.S.C. contains federal bankruptcy laws and details of the bankruptcy process. Title 11 is commonly referred to as the "Bankruptcy Code". Companies can either file for bankruptcy under Chapter 7 (Liquidation) or under Chapter 11 (Reorganization) of the Bankruptcy Code. Under Chapter 7, a trustee will liquidate the debtor's assets after the company ended its operations to pay creditors in line with the regulations of the Bankruptcy Code. By contrast, Chapter 11 provides the debtor with the possibility to present a reorganization plan while keeping its business alive and paying creditors according to a renegotiated schedule.

For a voluntary filing pursuant to 11 U.S.C. $\S 301$ there is no requirement stating that the debtor has to be insolvent or unable to pay its debts to file for Chapter 11 protection. Chapter 11 is designed to provide a debtor with the best possible options for a successful reorganization. Therefore, such an insolvency criterion is not integrated in the bankruptcy code because otherwise it might already be too late for an effective reorganization. However, for an involuntary filing instituted by creditors certain financial requirements have to be fulfilled (11 U.S.C. $\S 303(b)$ ). The absence of a financial requirement to institute a voluntary filing leads to the question how companies are prevented from using Chapter 11 as a mere business instrument.

A court shall confirm a Chapter 11 reorganization plan only if "the plan has been proposed in good faith and not by any means forbidden by law” (11 U.S.C. § 1129 (a)(3)). Therefore, the bankruptcy court has a little manoeuvring room in this regard. Nevertheless,

\footnotetext{
1 There is a limited number of studies that capture the effect of Chapter 11 on the airline industry. Predominantly, they consider the effect on prices in the US domestic market (Borenstein and Rose, 1995; Barla and Koo, 1999; Ciliberto and Schenone, 2012).

${ }^{2}$ While we conclude that access to bankruptcy laws shall not being considered as a formal form of a subsidy, it can still be perceived as a locational advantage of being registered in a particular country. Namely, similar to tax and labor laws, bankruptcy falls into this same class of advantages (or disadvantages).
} 
the request to dismiss a Chapter 11 filing could arise earlier in the process. 11 U.S.C. $\S 1112$ (b) (4) provides a list of possible causes which allow the court to dismiss or convert a Chapter 11 case. However, insolvency and "bad faith" are not included as possible causes. However, US "courts have consistently found that the prosecution of a chapter 11 case in 'bad faith' - although not listed as one of the examples - also constitutes 'cause' for dismissal or conversion under section 1112(b)" (Leake, 2004). Consequently, firms cannot easily use Chapter 11 as a mere business tool to cut down cost even if financial healthy because chances are high that such a case will be dismissed by court if the debtor cannot provide reasonable arguments for the bankruptcy filing.

Chapter 11 provides manifold opportunities for financial distressed firms to reduce costs. We will focus on the six most important cost reduction possibilities available to Chapter 11 debtors. Table 1 provides a short overview of the six possibilities and it summarizes their key aspects. 
Table 1: Core cost reduction opportunities under Chapter 11

\begin{tabular}{|c|c|}
\hline $\begin{array}{l}\text { ost reduction } \\
\text { ossibilities }\end{array}$ & S \\
\hline $\begin{array}{l}\text { Renegotiation of } \\
\text { Prepetition Debts }\end{array}$ & $\begin{array}{l}\text { Creditors' claims are divided into secured claims, unsecured } \\
\text { priority claims, unsecured nonpriority claims and equity } \\
\text { security interests. Negotiated exit strategies usually include } \\
\text { payment over time or conversion of debt to equity. Under } \\
\text { certain conditions a court can force changes on creditors. }\end{array}$ \\
\hline $\begin{array}{l}\text { Rejection of } \\
\text { Executory Contracts }\end{array}$ & $\begin{array}{l}\text { Executory contracts under Title } 11 \text { are contracts "for which } \\
\text { performance remains due to some extent on both sides" } \\
\text { (Buchbinder and Cooper, 2009, p.202). A debtor can either } \\
\text { reject or assume and cure any executory contract under a } \\
\text { Chapter } 11 \text { filing at any time before the confirmation of the } \\
\text { Chapter } 11 \text { plan. }\end{array}$ \\
\hline $\begin{array}{l}\text { Rejectic } \\
\text { Leases }\end{array}$ & $\begin{array}{l}\text { In regard to aircraft leases, the debtor basically has options } \\
\text { similar to the treatment of executory contracts with some } \\
\text { restrictions providing increased security to lessors. }\end{array}$ \\
\hline $\begin{array}{l}\text { Modification of } \\
\text { Collective } \\
\text { Bargaining } \\
\text { Agreements (CBAs) }\end{array}$ & $\begin{array}{l}\text { If negotiations with an authorized representative of the } \\
\text { employees fail, but the proposal was rejected without "good } \\
\text { cause" and the modifications are "necessary" for the company } \\
\text { to reorganize, a CBA can be unilaterally changed with court } \\
\text { approval. }\end{array}$ \\
\hline $\begin{array}{l}\text { Termination of } \\
\text { Pension Plans }\end{array}$ & $\begin{array}{l}\text { The Bankruptcy Code does not confer the right to terminate a } \\
\text { pension plan, except in specific circumstances. Employee } \\
\text { Retirement and Income Security Act (ERISA) regulations } \\
\text { allow for two options to terminate a defined benefit plan. In } \\
\text { case of such a termination, the Pension Benefit Guaranty } \\
\text { Corporation (PBGC) will insure the payment of these plans } \\
\text { while filing claims against the debtor. }\end{array}$ \\
\hline $\begin{array}{l}\text { Modification of } \\
\text { Retiree Benefits }\end{array}$ & $\begin{array}{l}\text { The process to modify retiree benefits is similar to the process } \\
\text { of modifying CBAs. }\end{array}$ \\
\hline
\end{tabular}




\section{$3 \quad$ What is a subsidy?}

In order to address the question if Chapter 11 should be regarded as a subsidy, there are two possible perspectives: a legal perspective and an economic one. In this section, these concepts are discussed and compared.

\subsection{The Legal Perspective}

WTO (World Trade Organization) regulations and bilateral/multilateral Air Service Agreements constitute the main sources of applicable public international laws. The latter sometimes do, and sometimes do not, mention subsidies and their effects on competition between airlines from different countries. However, typically they do not define in detail what a subsidy is. Thus, we concentrate on the WTO definition.

It should be noted that while we are setting out "legal" definitions, because the General Agreement on Tariffs and Trade (GATT) and General Agreement on Trade in Services (GATS) exclude airlines except in some minor ways, the definitions we are discussing do not have legal force. We are essentially setting out how subsidies might be defined, if air transport were handled in the same way as goods are treated in the GATT.

\subsubsection{World Trade Organization}

The WTO was founded 1995 as an international organization. Whereas services are regulated by the GATS, air transport services are nearly totally excluded from GATS regulations (Annex on Air Transport Services, GATS). However, competition law is still applicable via the former GATT and remains in force as a kind of umbrella treaty. Nevertheless, the WTO disciplines on subsidies in regard to industrial goods are today primarily contained in the Agreement on Subsidies and Countervailing Measures (SCM Agreement) which was established in the Uruguay Round (Ehlermann and Goyette, 2006).

Article 1.1(a)(1) SCM defines the term subsidy in the context of WTO regulations as follows: "there is a financial contribution by a government or any public body within the territory of a Member [...] or there is any form of income or price support [...] and a benefit is thereby conferred."

This definition reveals two criteria which are important for the definition of a subsidy: the financial and the benefit criteria. Those two criteria will be discussed in greater detail 
below. Furthermore, there is a third criterion, the specificity criterion. The specificity criterion is not important in regard to the definition of a subsidy. However, it is important in order to decide if further parts of the SCM are applicable or not (Article 1.2 SCM). Because this is beyond the scope of interest in regard to the fact that the SCM agreement does not apply to aviation, the specificity criterion will just be briefly introduced below for the sake of completeness.

\subsubsection{The Financial Criterion}

There is "financial contribution" pursuant to Article 1.1(a)(1) SCM where:

i. a government practice involves a direct transfer of funds (e.g. grants, loans, and equity infusion), potential direct transfers of funds or liabilities (e.g. loan guarantees);

ii. government revenue that is otherwise due is foregone or not collected (e.g. fiscal incentives such as tax credits);

iii. a government provides goods or services other than general infrastructure, or purchases goods;

iv. a government makes payments to a funding mechanism, or entrusts or directs a private body to carry out one or more of the type of functions illustrated in (i) to (iii) above which would normally be vested in the government and the practice, in no real sense, differs from practices normally followed by governments.

Ehlermann and Goyette (2006) point out two important aspects about this definition:

a) the use of the term "i.e." in Article 1.1(a)(1) SCM indicates that the list is exhaustive, but the rather broad wording of the four measures opens a large scope of potential financial contributions;

b) the recognition under subparagraph (iv) that a financial contribution is granted when a government directs a private body to provide a financial contribution under subparagraph (i) to (iii) suggests that in this regard the definition of a subsidy under the SCM agreement is broader than under EU law. 


\subsubsection{The Benefit Criterion}

In addition, the recipient has to have a benefit through the financial contribution, otherwise it will not be consider as a subsidy in the WTO context. However, the definition of a benefit is a complex issue. Article $14 \mathrm{SCM}$ provides some guidelines on how a possible benefit shall be calculated. First of all, Article 14 SCM states that any method used for calculating a possible benefit shall be transparent and adequately explained.

Some explicit guidelines are provided by Article 14 SCM (a) to (d) for government provisions of equity, government loans, government loan guarantees and the provision of goods or services or purchase of goods by a government. In those cases, the benefit is measured as the difference between the conditions provided by the government and prevailing commercial market conditions.

For example, if the government provides a loan to company, a benefit would exist if there is a difference between the amount the firm pays on the government loan and the amount the firm would have to pay on a comparable commercial loan.

Therefore, a financial contribution of the government is not sufficient to constitute a subsidy. Solely the combination of the financial criterion and the benefit criterion constitute a subsidy under the SCM agreement.

However, Article $14 \mathrm{SCM}$ does not provide an exhaustive guideline on how to specifically calculate a recipient's benefit. Nevertheless, it specifies the market as a benchmark in order to assess the question of benefits.

\subsubsection{The Specificity Criterion}

The specificity criterion is important in order to decide if the parts on prohibited subsidies, actionable subsidies and countervailing measures are applicable or not. The criterion has no influence on the definition of a subsidy itself. (Article 1.2 SCM).

Ehlermann and Goyette (2006) identify three principles in regard to specificity and Article 2 SCM:

(1) De jure specificity: This exists if access to a subsidy is explicitly limited to certain enterprises.

(2) Presence of objective criteria: specificity does not exist where objective criteria are established which are neutral and do not favour certain enterprises over others, and 
which are economic in nature and horizontal in application, such as number of employees or size of enterprise.

(3) De facto specificity: If there are reasons to believe that a subsidy may in fact be specific, even in the absence of explicit limitation to certain enterprises or the presence and adherence to objective criteria or conditions, other factors will be considered.

Because the specificity criterion does not play an important role in the scope of this work, the three principles will not be reviewed in greater detail.

\subsection{The Economic Perspective}

In contrast to the legal perspective, the economic perspective of subsidies is extremely vague. Gössling et al. (2017) address the topic of subsidies in aviation and discuss the importance of different definitions. With respect to the economic perspective, they follow an Organisation for Economic Co-operation and Development (OECD) definition on subsidies. This is a specific definition which is used in a specific context, namely that of environmentally harmful subsidies. The OECD defines a subsidy as "any measure that keeps prices for consumers below market levels, or for producers above market levels, or that reduces costs for consumers or producers" (OECD, 2005, p. 114).

In comparison to the legal definitions discussed above, the OECD definition is much broader and less specific. The first part of the OECD definition defines a measure as a subsidy if prices are kept below/above prevailing market conditions for consumers/producers. The reference to market conditions is similar to the benefit criterion in WTO and EU definitions of subsidies. However, the OECD definition refers to any measure whereas the WTO and EU definitions require the respective financial criteria to be fulfilled which are more restricting than the broader OECD approach.

The second part of the OECD definition particularly addresses the topic of costs and covers the case that even if a measure does not influence prices, but leads to reduced costs, it should be regarded as a subsidy.

The second part of the OECD definition is especially interesting in regard to Chapter 11 because, in contrast to the WTO and the EU definition, the OECD definition does not require state resources to be involved. The reductio ad absurdum is that the whole Chapter 11 
process would constitute a "subsidy" because where the financial contribution respectively cost savings are derived from is not important in regard to the OECD definition. But is this what the OECD means?

What is clear from the context of the report is that a subsidy refers to a government or state subsidy, paid for by the taxpayer out of the government budget. Reading the whole of the OECD report, the term subsidy only refers to state subsidies - the possibility of subsidies funded from other sources is not considered.

This is so for other references to subsidies in the economics literature. For example, classic writers on public economics, such as Shoup (1972) are quite clear that subsidies are paid by governments: "The economic theory of subsidy payments is the theory of how government can induce changes in relative prices $[\ldots]$ in the private sector $[\ldots]$ ”. In its World Trade Report 2006, the WTO discusses subsidies and trade, but does not allow anything other than subsidies provided by the government (WTO, 2006). Gossling et al. (2017) only speak of government subsidies.

Thus, in the economics literature, if the term subsidy is used, it refers to government subsidies, unless otherwise qualified.

There are some examples of non-government subsidies - an important one is crosssubsidies, whereby a firm takes resources from one of its divisions to give to another. Typically, these do not involve the government as the source of the funds. Subsidies are qualified in other ways. For example, the term "hidden subsidies" is used to describe government subsidies which have been masked in some way, and tax-subsidies refers to subsidies which have been created using the tax system.

\section{$4 \quad$ Evaluation of Chapter 11}

In this section, we evaluate the opportunities for cost reduction as induced by the Chapter 11 process, we then focus on the termination of the pension plans and conclude by assessing whether Chapter 11 actually involves a subsidy.

\subsection{Opportunities for Cost Reduction under Chapter 11}

In this section, the above criteria for subsidies are used to evaluate the following six opportunities Chapter 11 offers to reduce costs. 
a) Renegotiation on Pre-petition Debts

b) Rejection of Executory Contracts

c) Rejection of Aircraft Leases

d) Modification of CBA

e) Termination of Pension Plans

f) Modification of Retiree Benefits

We briefly discuss these opportunities below.

\section{a) Renegotiation on Pre-petition Debts}

Because the consent of the majority of creditors is required to get the Chapter 11 plan approved by the courts, it provides the debtor with a means of getting rid of some claims, at least partially (Salerno et al., 2010). The US has a long history of privately owned airlines compared to other countries (Cappelli, 1995), which means that, in most cases the state or public bodies will not be creditors in this regard. Therefore, the crucial element in regard to most subsidy definitions (a support measure has to be granted from the state or through a state or a public body) will most probably not be fulfilled in regard to treatment of prepetition debts. ${ }^{3}$ However, if the state or a public body is a creditor, things could turn out differently.

\section{b) Rejection of Executory Contracts}

Executory contracts under Chapter 11 are contracts "for which performance remains due to some extent on both sides" (Buchbinder and Cooper, 2009). Licence agreements, real estate leases or equipment leases would be examples for executory contracts.

11 U.S.C. $\S 365$ provides the debtor with the possibility to either reject or assume executory contracts under a Chapter 11 filing at any time before the confirmation of the Chapter 11 plan by the court. In the US, commercial airports are in most cases run through a form of partnership of federal, state and local government and the private sector (Airport Cooperative Research Program, 2012).

Therefore, it could be possible, e.g. in regard to rejected gate or terminal leases, that the government appears as a creditor with a pre-petition general unsecured claim. In such a

\footnotetext{
${ }^{3}$ The date on which the bankruptcy is filed is referred to as the petition date. There are three stages: the prepetition date, the post petition, and the post confirmation stages. Pre-petition debts are those accrued prior to the filing of the case.
} 
special case, one could argue that if the unsecured claim is impaired, this would constitute some form of financial contribution by the state or a public body. Thus, a rejected executory contract under Chapter 11 could fulfil the crucial criterion for subsidies in such a special case.

In conclusion, $\S 365$ can be a tool for an airline debtor to reject prematurely real estate leasing contracts for estates (e.g., for gates, terminals, hangars, office buildings) that either suffer from expensive rents or are not essential for the operation and reduce operating costs. Since most contracting parties in the airline industry are private companies, the rejection of executory contracts will most probably not fulfil the majority of definitions of subsidies.

\section{c) Rejection of Aircraft Leases}

11 U.S.C. $\S 1110$ exclusively refers to the airline industry, specifically to aircraft equipment rentals. It is applicable to leased aircraft, aircraft engines and spare parts as defined in 11 U.S.C. $\S 1110(a)(3)$. The majority of aircraft lessors are private companies. Therefore, the financial benefit for the debtor in the case of a rejected leasing agreement is derived from those private firms. Consequently, a rejected aircraft lease contract will not fulfil the majority of definitions of subsidies.

\section{d) Modifications of a Collective Bargaining Agreement (CBA).}

$\S 1113$ contains regulations concerning modifications to or rejection of a Collective Bargaining Agreement (CBA). In order to assess the importance of $\S 1113$ the following two points should be taken into account. The costs of wages and associated social security and pension payments account for a large part of an airline's operating costs. Doganis (2010) estimated the share of labour costs for European and American carriers in the year 2007 to be around $25 \%$ of total operating costs. For low cost carriers the values were about half as much.

In conclusion it can be said, that $\S 1113$ provides a means to the debtor to cut down wages and other labour contract terms which would not be possible under normal circumstances. These options can have a high impact on a debtors total operating costs because of the high share of labour costs within an airlines cost portfolio. However, because the employees are basically "paying the check", modifications of CBAs will not fulfil any of the normal definitions of subsidies. 


\section{d) Termination of Pension Plans}

The Bankruptcy Code does not confer the right to terminate a pension plan by the debtor (Resnick and Sommer, 2016, para. 12.08). But, as mentioned above, the Bankruptcy Code could be a necessary means to create the required preconditions to terminate a pension plan under ERISA regulations. In particular, e) may involve recourse to support from a public body, and thus, under some definitions, may involve access to a subsidy. We explore this in detail in the following sub section (§4.2).

\section{e) Payment of Retiree Benefits}

Besides the renegotiation of CBA terms and the possibility to terminate pension plans during bankruptcy, the Bankruptcy Code addresses the issue of retiree benefits as well. Retiree benefits are defined as "payments for retired employees and their spouses and dependents, for medical, surgical, or hospital care benefits, or benefits in the event of sickness, accident, disability, or death" (11 U.S.C. § 1114(a)).

The financial benefit for the debtor is, similar to the case of modifications to CBAs, directly derived from the employees due to curtailments in regard to the retiree benefits initially agreed upon. Consequently, modifications of retiree benefits will not fulfil the core criterion of most definitions on subsidies.

In conclusion, it can be said that $\S 1114$ is an important supplement to $\S 1113$ on CBAs and to the ERISA regulations on pension plans. However, unlike the termination of pension plans, the modification of retiree benefits will not fulfil any of the normal definitions of subsidies.

Since we conclude that only e) may meet the criteria, we, therefore, further elaborate on this opportunity.

\subsection{Termination of Pension Plans}

While a complete coverage of this topic is beyond the scope of this work, some background information is necessary in order to understand the termination process of pension plans. In the US, two broad types of pension plans exist: defined benefit plans and defined contribution plans.

Defined contribution plans are plans in which contributions are placed in individual accounts and the accumulated amount is distributed in a specified manner upon retirement. 
Employee contributions are voluntary but usually contributions are made by both the employer and the employee. Defined contribution plans are not insured, because the employer is not allowed to use the money in the respective saving accounts for any other purpose. Therefore, defined contribution plans do not play any role in bankruptcy cases because they cannot be underfunded (Elliott, 2009).

Defined benefit plans provide a clearly defined benefit upon retirement based on years of service and earned wage. Employee Retirement and Income Security Act (ERISA) regulations define minimum funding requirements. However, variations in investment performance and the firms' abilities to defer payments under certain conditions pose a risk of those plans to be underfunded at a certain point in time. Therefore, the Pension Benefit Guaranty Corporation (PBGC) was founded 1974 under ERISA to insure the payment of these plans (Elliott, 2009). The PBGC is an established body within the Department of Labour pursuant to 29 U.S.C. $\S 1302$. Thus, the PBGC is a federal agency.

There are basically two different types of insured pension plans: single-employer plans and multi-employer plans. In single-employer plans the PBGC pays plan benefits in the case of a plan termination if the plan does not have enough assets upon this date, whereas multiemployer plans are maintained by several companies and labour unions together within the same industry. In multi-employer plans, the PGBC acts in a similar fashion to a re-insurer, because if a plan sponsor withdraws from a plan, the liabilities are assumed by the remaining firms (Office of Management and Budget, 2016).

The PBGC obtains funding from insurance premiums from plan sponsors, investment income and recoveries obtained from actions against firms formerly responsible for the plans, without the involvement of general tax revenues (Pension Benefit Guaranty Corp, 2015).

There are two different types of insurance premiums: flat rate and variable rate. Flat rate premiums have to be paid on a per person basis by all plans. The variable premiums only have to be paid by some underfunded plans. However, the different rates are set by Congress and the PBGC is not allowed to adjust the rates taking into account, e.g., the risk of a certain plan (Office of Management and Budget, 2016).

Another funding source of the PBGC is investment income. With \$392 million investment income in the financial year 2015, it is however a smaller source of income 
compared to the $\$ 4.35$ billion of received insurance premiums (Pension Benefit Guaranty Corp, 2015). The PBGC is primarily focussing on investments with small risks such as US government securities (Pension Benefit Guaranty Corp, 2015).

Upon termination of pension plans, the PBGC tries to recover the difference between the liabilities of the plan and the value of the plan's assets from the former plan sponsor. Such claims are treated as nonpriority general unsecured claims and are often impaired under a Chapter 11 plan. Therefore the PBGC usually only recovers small parts of such claims (Elliott, 2009).

At the end of 2015, the single-employer and the multi-employer plans were underfunded by $\$ 76$ billion, and therefore the budget proposed to further increase premiums and give the PBGC the authority to adjust them (Office of Management and Budget, 2016). Nevertheless the PBGC has enough assets to pay benefits for a number of years (Office of Management and Budget, 2013).

ERISA regulations basically allow for three options to terminate a defined benefit plan: a standard termination according to 29 U.S.C. $\S 1341$ (b), a distress termination by the plan sponsor if certain criteria are met (29 U.S.C. $\S 1341(c)(2)(B)$ ) or an involuntary termination by the PBGC pursuant to 29 U.S.C. $\S 1342(a)$. Both, the distress termination and the involuntary termination, could be applicable in the scope of a Chapter 11 case.

Any company can terminate pension plans (if not prohibited by CBAs in force) via a standard termination at any time. However, upon plan termination, the plan has to be fully funded and all benefits have to be either paid to beneficiaries via lump-sum payments or via purchased private annuities (Munnell and Soto, 2007).

Instead of terminating pension plans, freezing a plan is another option to cut down long term financial obligations. Freezing pension plans basically means that the defined benefit plans for employees remain ongoing and the same funding requirements have to be met as before. However, depending on the type of a freeze, certain restrictions apply. In a "closed freeze" no new employees can join the plan but plan participants continue to accrue benefits. In a "hard freeze" all benefit accruals are stopped. In a "soft freeze" employees cannot earn future benefits through further years of service but for salary increases (Munnell and Soto, 2007). Therefore, by freezing a plan, financial obligations are reduced without the immediate 
payment requirements as in a standard termination. Both options can be exercised any time, if allowed in the scope of applicable CBAs.

If a debtor wants to transfer the liabilities of an underfunded plan to the PBGC, a distress termination has to be initiated. Therefore, the so called "distress criteria" pursuant to 29 U.S.C. $\S 1341$ (c)(2)(B) have to be met. The most important one is that "the bankruptcy court [...] determines that, unless the plan is terminated, such person will be unable to pay all its debts pursuant to a plan of reorganization and will be unable to continue in business outside the chapter 11 reorganization process and approves the termination" (29 U.S.C. § 1341(c)(2)(B)(ii)(IV)).

If the PBGC wants to terminate a pension plan in the context of a bankruptcy case, it typically relies on 29 U.S.C. $\S 1342(a)(4)$ (Lewis and Melwani, 2006). The argumentation of this paragraph is as follows: if there are reasons to believe that the long-run losses to be expected by the PBGC would increase if the plan is not terminated, the PBGC can institute a termination proceeding. The outcome of such an involuntary termination is basically equal to a distress termination initiated by the Chapter 11 debtor.

Large cost saving could be achieved with a distress or involuntary termination during a Chapter 11 case. The assumed liabilities by the PBGC through the pension plan terminations of United Airlines, US Airways and Delta Air Lines are in the top ten of the largest liabilities assumed by the PBGC between 1975-2014 (Office of Management and Budget, 2016).

Upon an involuntary or distress termination of a pension plan, the PBGC could have three types of claims against the debtor in order to try to recover at least parts of the assumed liabilities of a terminated pension plan. First of all, the so-called "unfunded benefit liabilities claim" (difference between the liabilities of the plan and the value of the plan's assets). Secondly, there could be a claim for unpaid minimum funding contributions and thirdly, a claim for unpaid pension plan termination insurance premiums. (Lewis and Melwani, 2006, p. 166)

The further development of those claims is dependent on several factors. If the pension plan is terminated before the plan sponsor files for Chapter 11 protection, the automatic stay prevents the PBGC in the first place to enforce its claims. If the plan is terminated after the bankruptcy filing, different procedures apply. According to Lewis and Melwani (2006), PBGC claims are in most cases treated as nonpriority general unsecured claims. This 
classification has a major impact on the amount of funds the PBGC can get from the debtor under a reorganization plan.

Consequently, despite the point that Chapter 11 itself does not confer the right to terminate pension plans as of right, the fact that a company is under Chapter 11 protection and the severity of the financial situation might fulfil the criterion for a distress termination or lead to an involuntary termination by the PBGC. A distress termination would not be available to firms outside of Chapter 11 protection. Furthermore, the option to modify CBAs under Chapter 11 could clear the way for every option discussed above in the case that current CBA terms restricted them from being exercised.

The financial benefit for the debtor in the case of a distress or involuntary termination is directly derived from the PBGC because the PBGC assumes the liabilities of the respective plans upon termination. Because the PBGC is a public body within the Department of Labour such a termination proceeding will fulfil some of the definitions of subsidies, even if the PBGC obtains its funds without using taxpayers' money. However, some narrower definitions on subsidies may require the involvement of tax money to classify a support measure as a subsidy.

This discussion shows that the termination of pension plans and the assumption of the liabilities through the PBGC is the most critical strategy in regard to the six core cost reduction possibilities and the question of whether Chapter 11 should be considered as involving a subsidy. However, in recent Chapter 11 cases (e.g., the American Airlines case), pension plans were not terminated but frozen, induced through a more aggressive approach of the PBGC in order to avoid large claims by the debtor. Such a procedure, like a standard termination, does not involve PBGC money and therefore the argument with respect to the term subsidy turns out differently.

In conclusion, it can be said that the ERISA termination options for pension plans can lead to a major cost relief for Chapter 11 debtors. The termination of pension plans is a highly complex topic and this section is solely intended to provide a brief overview of the associated issues. 


\subsection{Does Chapter 11 involve a Subsidy?}

Under the economic perspective, Chapter 11 does not involve a subsidy (unless the extreme interpretation of the OECD definition is adopted). There is no transfer from the taxpayer or the government budget to the airline undergoing Chapter 11 bankruptcy. Of the six opportunities in which costs can be reduced, five of them involve transfers from other bodies, specifically the shareholders of the airline or its employees.

The final opportunity for cost reduction involves termination of pension plans, under specific conditions. However, this does not involve any transfer from the government. The PBGC is an insurance agency. Under Chapter 11, under very specific conditions, the PBGC takes over the pension liabilities of the airline. The PBGC is a self-funded agency which derives its income, primarily, from charging airline (and other) participants premiums, like other insurance agencies or companies. It would seem strange that making a successful claim from an insurance company or agency, which the government does not contribute to, should be regarded as gaining a "subsidy".

Under the legal perspective, matters are more complicated. Using the WTO definition most of the avenues for cost reduction afforded by Chapter 11 do not apply, since the most of them are paid for by the shareholders or workforces of the airline. The exception is termination of pension plans.

In case of a termination of a pension plan of an airline the PBGC will taking over the payments. For there to be a subsidy, there needs to be a "financial contribution" from a "public body". The PBGC is a public body, and to this extent, the terms of the WTO definition is met. However, it needs to be recognised that the PBGC is an insurance agency, which is not funded by the government, but rather, funded by premiums of the firms participating in the scheme. When an airline enters Chapter 11, it makes a claim under its insurance policy. Does this constitute a "financial contribution"? Only if this is deemed to be the case, would there be a subsidy.

\section{$5 \quad$ Chapter 11 and International Subsidy Disputes}

Allegations that Chapter 11 embodies an element of subsidy have featured in two recent international aviation disputes. The first of these concerns the operation of the EU-US (Open 
Skies) Air Transport Agreement. A more recent, and much more contentious, dispute is that concerning the claim by the three major US airlines that the Gulf airlines are competing unfairly because they have access to large government subsidies. We consider each of these in turn.

\subsection{Chapter 11 and the EU-US Open skies negotiations}

In the tenth meeting of the U.S.-EU Joint Committee in 2011 the European delegation expressed its concerns about possible distortionary effects of American Airlines filing for Chapter 11 on the competitive situation on the North Atlantic market. Furthermore, the delegation stated that they view Chapter 11 as a government subsidy. The U.S. delegation took an opposite point of view. (U.S.-EU Joint Committee, 2011)

The minutes of the Joint Committee meeting emphasizes the importance of Chapter 11 in relation to the North Atlantic. In the subsequent meetings of the Joint Committee the discussion in regard to Chapter 11 was not continued. Instead, a few updates on the ongoing Chapter 11 process were given, and the possible merger between American Airlines and US Airways was briefly addressed (U.S.-EU Joint Committee, 2012, 2013).

In contrast to the US-UAE case (see §5.2), the EU-US Air Transport Agreement (ATA) contains a specific article on subsidies with a rather broad definition. Yet, despite the fact that the definition in Article 14 of the EU-US ATA does not contain elements such as the benefit and specificity criterion in the SCM definition and furthermore defines the financial contribution aspects very openly in a non-exhaustive list, the key point of the government entity remains. Therefore, it would be difficult to identify other aspects of Chapter 11 that would fit the definition except pension plans. While the EU delegation would have some good ground to base their claim on pension plans their position was weakened by a change in the American Airlines bankruptcy case.

American Airlines initially sought to terminate its pension plans. However, this was rejected by the bankruptcy court. On May 4, 2012, American Airlines reached an agreement with the PBGC not to terminate the pension plans but to freeze them. Freezing the plans basically means that the defined benefit plans for employees remain ongoing but employees cannot earn future benefits through further years of service and no new employees can join the plan (Seider et al., 2015). Therefore, there were no costs to the PBGC in this case and subsequently, the PBGC withdrew all its claims on February 11, 2014. To conclude, a 
pension plan freeze represents a compromise - the debtor can shed future commitments that would arise under the plan otherwise, but there are no costs to the PBGC because the debtor remains responsible for paying the benefits that added up until the time of the freeze.

\subsection{Chapter 11 and the US-Gulf Airlines Subsidy Dispute}

This dispute began when the three major US airlines (American, United and Delta) published a paper (Partnership for Fair and Open Skies, 2015) which alleged that the three large Gulf airlines (Emirates, Etihad and Qatar Airways) were competing unfairly on their routes to the US because they had access to large subsidies from their governments. The former called on the US government for action. The Gulf airlines responded by claiming that Chapter 11 bankruptcy proceedings constituted a form of subsidy to the US airlines. At this stage, the US government has investigated the claims, though it has not taken any substantive action, and the dispute is far from settled.

In their original claim, the US airlines were not admitting that their recourse to Chapter 11 gave them any advantage or was a subsidy. However, they did use the WTO definition of a subsidy, even though, as Emirates pointed out, it was not appropriate, given that airlines are not covered by the GATT or GATS (except in minor ways). Nevertheless, Emirates did take the WTO definition as a convenient and relevant definition, even though it does not have legal force in the airline case.

We consider the legal and economic perspectives in turn. If the WTO definition were applied, it is possible that some aspects of Chapter 11 might be construed as a subsidy. In particular, the termination of pension plans might be regarded as a subsidy. The PBGC is a public agency, and having this body take over pensions might be construed as the airline receiving a "financial contribution" from it (even though it has paid for it through its premiums). In its response to the "White Paper", Emirates (2015) claims that the termination of pension plans does constitute a subsidy, which may be so if the WTO definition is used. However, it also claimed that relief of debts also involves a subsidy, though it does not show that this comes about through a public body.

The economic perspective is more straightforward. None of the avenues which Chapter 11 affords necessarily involves a grant or subsidy from the state. Shareholders and workforces are the source of the funding in most cases. Even though a public body is 
involved in guaranteeing pension plans, the PBGC is effectively an insurance agency which takes premiums from industry and pays out benefits back to firms under specific conditions. If there is any subsidy, it is a matter of industry subsidising itself.

\section{Conclusions}

The notion that Chapter 11 provides a subsidy to US airlines has been used in a number of international air transport disputes, and more recently, it has been raised in the context of the dispute between the US and the Gulf countries. In this paper, we have sought to explore whether access to Chapter 11 by the US airlines gives rise to avenues which could be defined "subsidies".

Much depends on how "subsidies" are defined. One approach is to consider public international law. The most relevant source of this is the definition, used by the WTO in its GATT and GATS agreements. However, neither of these applies to airlines - while airlines provide a traded service, they are almost entirely exempt from GATS. One critical aspect of this definition defines a subsidy as including funding from "public bodies" be it sourced from the government, or any other source, including the industry itself. There have been other definitions used by international bodies, such as the OECD. However, these have no legal force. Using an OECD definition, it might seem that Chapter 11 can give rise to subsidies, though it needs to be noted that this may be taking the definition out of context (it only considers subsidies which are funded by the government).

Economists often talk about subsidies, but they rarely define them in any specific way. However, it does seem that they understand subsidies, almost invariably, as being grants from the government, either directly or indirectly. In this respect, the definition is more specific than the WTO definition.

Chapter 11 creates six possible avenues for cost reduction. We consider these in detail, and conclude that only one, termination of pension plans, might involve a subsidy. All of the others involve either shareholders or workforces covering the cost. With Termination of Pension Plans, the airline may have access to funding of its plan by a public body, the Pension Benefit Guaranty Corporation (the PBGC), which is a public body. If one were use the WTO definition of a subsidy, this could be counted as a subsidy. On the other hand, this 
"subsidy" is funded by industry itself, through the premiums it pays to the PBGC. Using the economist's common view of a subsidy, this would not be counted as a subsidy, since industry not the government is paying.

We discuss two recent cases where Chapter 11 has been alleged to have involved a subsidy. The first case, involving the negotiations between the US and the EU over an open skies agreement, the European side were concerned about the workings of Chapter 11. The issue was not pursued, partly because over the period of the negotiations, Chapter 11 was not invoked to terminate any airline's pension plans. In the ongoing dispute between the US and Gulf carriers, it has been alleged that the US airlines have been subsidised via Chapter 11. Emirates, in its submission, correctly recognised that the WTO definition of subsidy is not applicable to airlines, but it adopts this definition as a convenient one, and argues that having pension plans being funded by "public body" constitutes a subsidy. However, it did not mention that this body is funded by industry premiums, and does not involve funding from the government. Under a normal economic definition of subsidy, this would not be regarded as a subsidy.

While not a subsidy, Chapter 11 offers US airlines the opportunity to restructure their business and compete with other non-US airlines more successfully. If and to what extent this opportunity is an advantage depends on many factors - after all, an insurance premium is not costless, and in most countries insolvency protection law offers similar opportunities. These issues demand further research. 


\section{References}

Airport Cooperative Research Program, 2012. Considering and Evaluating Airport Privatization, Washington: Transportation Research Board.

Barla P, Koo B. Bankruptcy protection and pricing strategies in the US airline industry. Transportation Research Part E, 1999; 35(2); 101-120.

Borenstein S, Rose N L. Bankruptcy and pricing behaviour in the US airline markets. American Economic Review, 1995; 85(2); 397-402.

Buchbinder, D. L. and Cooper, R. J., 2009. Basic Bankruptcy Law for Paralegals. Abridged edition, Aspen Publishers, New York.

Cappelli, P., 1995. Airline Labor Relations in the Global Era: The New Frontier. Cornell University, Ithaca.

Ciliberto F, and Schenone C., 2012. Bankruptcy and product-market competition: Evidence from the airline industry. International Journal of Industrial Organization, 30, 564-577.

Doganis R., 2010. Flying off course. Fourth edition. Routledge, London.

Ehlermann, C.-D. and Goyette, M., 2006. The Interface between EU State Aid Control and the WTO Disciplines on Subsidies. European State Aid Law Quarterly, 4, 695-718.

Elliott, D. J., 2009. A Guide to the Pension Benefit Guaranty Corporation, s.1.: Initiative on Business and Public Policy.

Emirates, 2015. Emirates' Response to claims raised about state-owned airlines in Qatar and the United Arab Emirates, Emirates Airline, June 29.

Gössling, S., Fichert, F., andForsyth, P., 2017. Subsidies in aviation, Sustainability 2017, $9(8), 1295$.

Hotchkiss, E.S., 1995. Postbankruptcy Performance and Management Turnover, Journal of Finance; 50, 3-21.

Jensen, M. C., 1991. Corporate Control and the Politics of Finance. Journal of Applied Corporate Finance; 4, 13-33.

Leake, P. D., 2004. Making the Case for a "Good Faith" Chapter 11 Filing. The bankruptcy strategist, November. http://www.jonesday.com/files/Publication/e07e38ed-fd3a-4695a1 e4-d2b90c0b933a/Presentation/PublicationAttachment/b8650228-a690-438c-b453eb32b96342a4/NYI_2173499_v1_GoodfaithfilingDecember\%202004\%20BRR.pdf 
Lewis, J. and Melwani, V., 2006. Treatment of Pension Plans When an Employer Is in Bankruptcy. Bender's Labor and Employment Bulletin, April, 6, 163-172.

Munnell, A. H. and Soto, M., 2007. Why are companies freezing their pensions? Center for Retirement Research at Boston College.

OECD, 2005. Environmentally Harmful Subsidies - Challenges for Reform, Paris: OECD.

Office of Management and Budget, 2013. Analytical Perspectives - Budget of the U.S. Government Fiscal Year 2014, Washington, U.S. Government Printing Office.

Office of Management and Budget, 2016. Analytical Perspectives - Budget of the U.S. Government Fiscal Year 2017, Washington: U.S. Government Printing Office Pension Benefit Guaranty Corp, 2015. PBGC Annual Report 2015.

Resnick, A. N. and Sommer, H. J., 2016. Collier Guide to Chapter 11: Key Topics and Selected Industries. LexisNexis.

Salerno, T. J., Kroop, J. A. and Hansen, C. D., 2010. The Executive Guide to Corporate Bankruptcy. Second edition, Frederick: Beard Books.

Seider, M. A., Williamson, B. L., Goodman, L. D. and Reilly, A. V., 2015. FAQ: Recent Developments in U.S. Law Affecting Pension and OPEB Claims in Restructurings. Pratt's Journal of Bankruptcy Law, 11, 389-420.

Shoup, C. S., 1972., The Economic Theory of Subsidy Payments, in United States Congress, Joint Economic Committee, The economics of federal Subsidy Payments. 1: General Study papers, Washington, D.C., pp. 307-321.

Tretheway, M. and Andriulaitis, R., 2015. What do we mean by a level playing field in international aviation?. Transport Policy 43, 96-103.

U.S.-EU Joint Committee, 2011. Tenth meeting of the US-EU Joint Committee Record of Meeting December $8^{\text {th }} 2011$;

available at http://www.state.gov/e/eb/rls/othr/ata/e/eu/192096.htm.World Trade Organization (WTO) 2006. World Trade Report 2006. Exploring the links between subsidies and trade, Geneva: WTO. 